\title{
INFLUENCE OF ROAD CONDITIONS ON VEHICLES' FUEL CONSUMPTION
}

\section{ВПЛИВ ДОРОЖНІХ УМОВ НА ВИТРАТИ ПАЛИВА АВТОМОБІЛІВ}

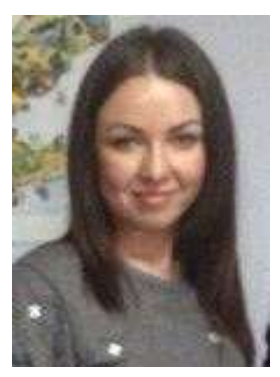

Dodukh KaterynaMyhaylivna, CTS, Docent at the Department of Road Design, Geodesy and Land Management. National Transport University. e-mail: ekaterinadodukh@gmail.com;тел.: (096)129-39-38

https://orcid.org/0000-0003-2544-5359

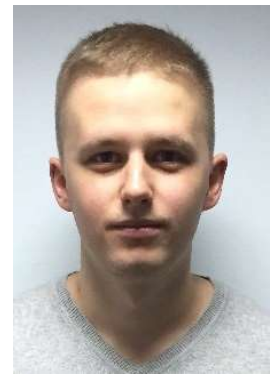

Palchyk Anton Dmytrovych, postgraduate student of department of tourism, National Transport University.e-mail: palchyk94@gmail.com; тел.: (063)121-14-51

https://orcid.org/0000-0002-1467-3658

Summary.The article deals with the influence of road conditions on fuel consumption by vehicles when transporting goods and passengers, which depends on the speed of movement. The optimum fuel consumption corresponds to the optimum speed of movement which is distinctive for each type of car. Increase or decrease of the optimum speed leads to increased fuel consumption. Elevations reduce the speed and increase fuel consumption by up to $30 \%$. Road conditions (width of roadway, condition of surface, presence of horizontal curves, longitudinal slopes, pedestrian crossings, settlements) cause a change in the speed of movement and consumption of fuel and lubricants. It is possible to take into account the road conditions by plotting the speed of movement along the route, the change in the speed occuring during the travel time and socioeconomic indicators of the route.

Based on this chart, fuel costs and route times are calculated. Since the cost of fuel is $50-52 \%$ of the cost of transportation of goods and passengers, the cost will be roughly 2 times higher. The cost of transportation of goods by trucks is characterized by the cost of transportation, and the transportation of passengers by the cost and time spent by passengers when traveling the route.

Keywords: road, car, speed, fuel consumption, route travel time.

Introduction. Transportation of goods and passengers is estimated by the route travel time.

Travel time depends on the type of vehicle, road conditions, weather conditions and traffic organization. The average speed of the car on individual sections of roads on the route may be the main criterion $(5,6,7,8)$. Road conditions determine the average speed of the car. Under road conditions, we mean geometrical parameters of the motorway (the width of the roadway, the number of lanes, the radii of horizontal curves, longitudinal slopes, the radii of vertical curves, the availability of settlements, pedestrian crossings) and the state of surface (coefficient of adhesion, flatness). The article considers the question of plotting the speed of 
the car by defined route and determination of fuel consumption by cars that affect the cost of transportation both for goods and passengers. Fuel costs depend on the type of vehicle, its purpose, average speed in various road and weather conditions, which increase with decreasing or increasing the speed of movement from optimal speed.

Purpose and methods. The cost of the route travel depends on fuel consumption and average speed of the car. The result will be the route travel time and its cost.

So the time of the route travel depends on the speed of the car, and this in turn depends on the geometry of the road and the type of car:

where : $\mathrm{V}=\mathrm{f}(\Pi, \mathrm{C}($ !)

$$
T=f(V . P),
$$

P- type of car,

П- road parameters,

C- state of surface.

The main criterion for the cost of freight transportation is the cost of fuel and lubricants. The cost of transportation of goods by highways consists of the cost and profit.

The cost of transportation of goods by cars is formed as follows ( 3,4$)$ :

$$
c=\left(C_{T}+C_{U}+C_{p}+C_{a}\right)+\frac{C_{I I}+C_{3 \Pi}}{V},
$$

where V- speed of the car ( $\mathrm{km} /$ hour);

Ст- fuel and lubricating material costs (uah $/ \mathrm{km})$;

Сш- the costs of tire wear (uah / km);

$\mathrm{Cp}$ - maintenance and repair costs (uah / km);

Ca- restoring costs and depreciation (uah / km);

Cп- fixed costs (uah/ hour);

Сзп- driver's wage (uah/ hour).

The costs considered can be divided into three groups. The first group depends on the car driving (uah / $\mathrm{km}$ ), second on the length of the journey (uah / h), third on the speed of cars $(\mathrm{km} / \mathrm{hour})$.

When examining the cost of driving a car the following must be taken into account: speed, length of the journey, length of the route.

The cost of fuel and lubricants, taking into account the cost of the length of the section of the road $1 \mathrm{~km}$.

$$
C_{T}=1.1 G s \cdot \bigsqcup_{T}
$$

where Gs - fuel consumption at $1 \mathrm{~km}(1)$;

Цт - cost of fuel (uah.)

$$
G s=f(V ; P),
$$

where P- type of car.

Tire wear costs:

$$
C_{\amalg}=\frac{0.1 \bigsqcup_{\amalg} \Pi_{\amalg} K_{\epsilon}}{H_{U}},
$$


where Цш - cost of tire, uah.;

Нш - the mileage is set at $1 \mathrm{~km}$;

Пш - number of tires;

Ke- takes into account road conditions.

Depreciation deductions:

$$
C_{a}=\frac{\lfloor a \cdot a}{1000} \cdot K_{\epsilon},
$$

where Ца - car cost, uah.;

$\mathrm{a}-$ the rate of depreciation deductions.

Maintenance and repair rates:

$$
C_{p}=H_{O T} K_{C},
$$

where Hoт - maintenance rates.

According to the data ( 4 ) part of expenses in percent.

Table 1 - Costs of transportation of goods and passengers

Таблиця 1 - Витрати на пебревезення вантажів і пасажирів

\begin{tabular}{|c|c|c|c|c|c|c|}
\hline $\begin{array}{c}\text { General } \\
\text { costs }\end{array}$ & $\begin{array}{c}\text { Fuel and lub- } \\
\text { ricants }\end{array}$ & $\begin{array}{c}\text { Depreciation } \\
\text { Costs }\end{array}$ & $\begin{array}{c}\text { Repair and ser- } \\
\text { vice }\end{array}$ & Fixed & Wage & Assignment \\
\hline 100 & 52 & 22 & 5 & 12 & 6 & 3 \\
\hline
\end{tabular}

It can be seen from the table that fuel and lubricants account for $52 \%$ of freight costs, while salaries and business trips make up $9 \%$, which together make up $61 \%$.

Fuel consumption is characterized by the type of car and the optimum speed, which can be expressed by the following graph:

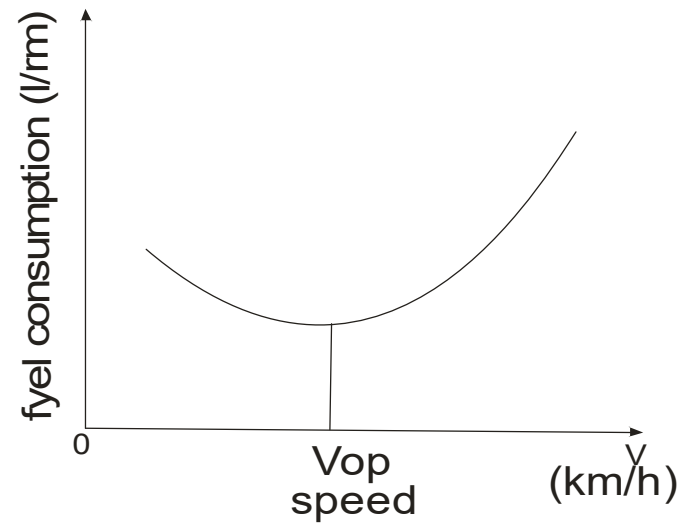

Figure 1 - Dependence of fuel consumption by the car on the speed of movement.

Рисунок 1 - Залежність витрат палива автомобілем від швидкості руху

The optimum speed depends on the type of vehicle and varies from $35 \mathrm{~km} / \mathrm{h}$ to $80 \mathrm{~km} / \mathrm{h}$.

Results and explanation. The speed of the cars depending on the geometry of the road is calculated as the decrease of the average free-movement speed from the number of lanes, the width of the lane, the radii 
of horizontal curves, the longitudinal slope and the equality of coverage, the passage of settlements, the planned solutions of crossings and adjacencies.

So the speed of free movement of cars on a horizontal straight section of the road, depending on the category of road and vehicle type, is given in Table 2

Table 2 - Average free traffic speed depending on the type of road and type of vehicle.

Таблиця 2 - Середні швидкості вільного руху в залежності від категорії доріг та типу автомобілів

\begin{tabular}{|c|c|c|c|c|c|c|}
\hline \multirow{2}{*}{ № } & \multirow{2}{*}{$\begin{array}{c}\text { Road cate- } \\
\text { gory }\end{array}$} & \multirow{2}{*}{$\begin{array}{c}\text { Number of } \\
\text { lanes }\end{array}$} & \multicolumn{4}{|c|}{ Average speed, km/hour } \\
\cline { 4 - 7 } & Ia & 6 & 91,13 & 75,70 & 77,50 & 81,03 \\
\hline 1 & Ia, Iб & 4 & 88,04 & 75,77 & 74,61 & 80,00 \\
\hline 2 & II & 2 & 84,29 & 71,90 & 71,50 & 72,93 \\
\hline 3 & III & 2 & 79,72 & 67,06 & 69,33 & 71,11 \\
\hline 4 & IV & 2 & 75,83 & 64,08 & 67,03 & 68,75 \\
\hline 5 & & & \multicolumn{3}{|c|}{} \\
\hline
\end{tabular}

Reducing average speed depending on the radius of the horizontal curve, taking into account the type of vehicle through its average length, depending on its size, is shown in Figures 2 and 3.

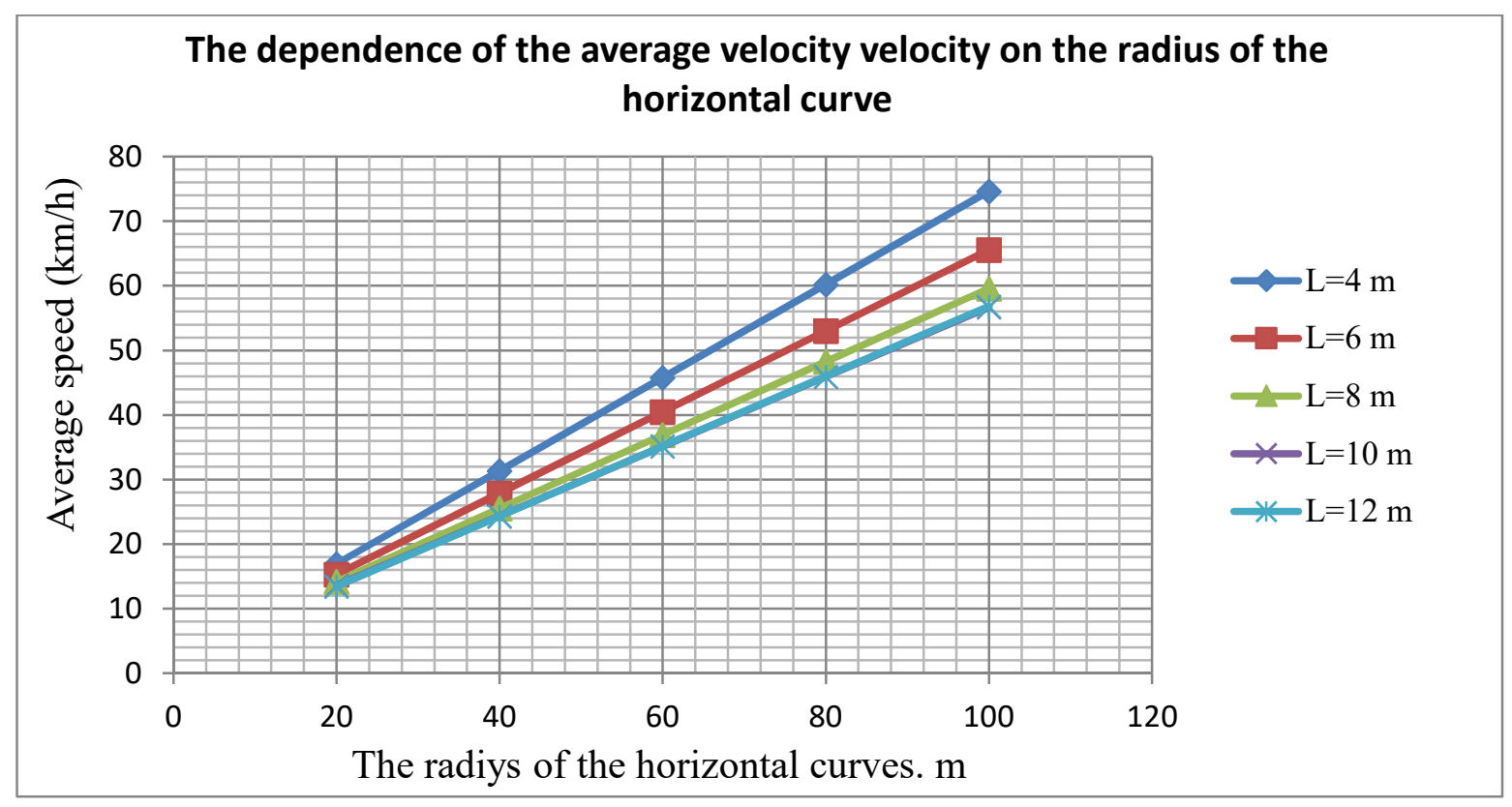

Figure 2 - Graph of the average speed depending on the radius of the horizontal curve up to $100 \mathrm{~m}$ and the average length of the car.

Рисунок 2 - Графік залежності середньої швидкості руху від радіуса горизонтальної кривої до 100 м та середньої довжини автомобіля 


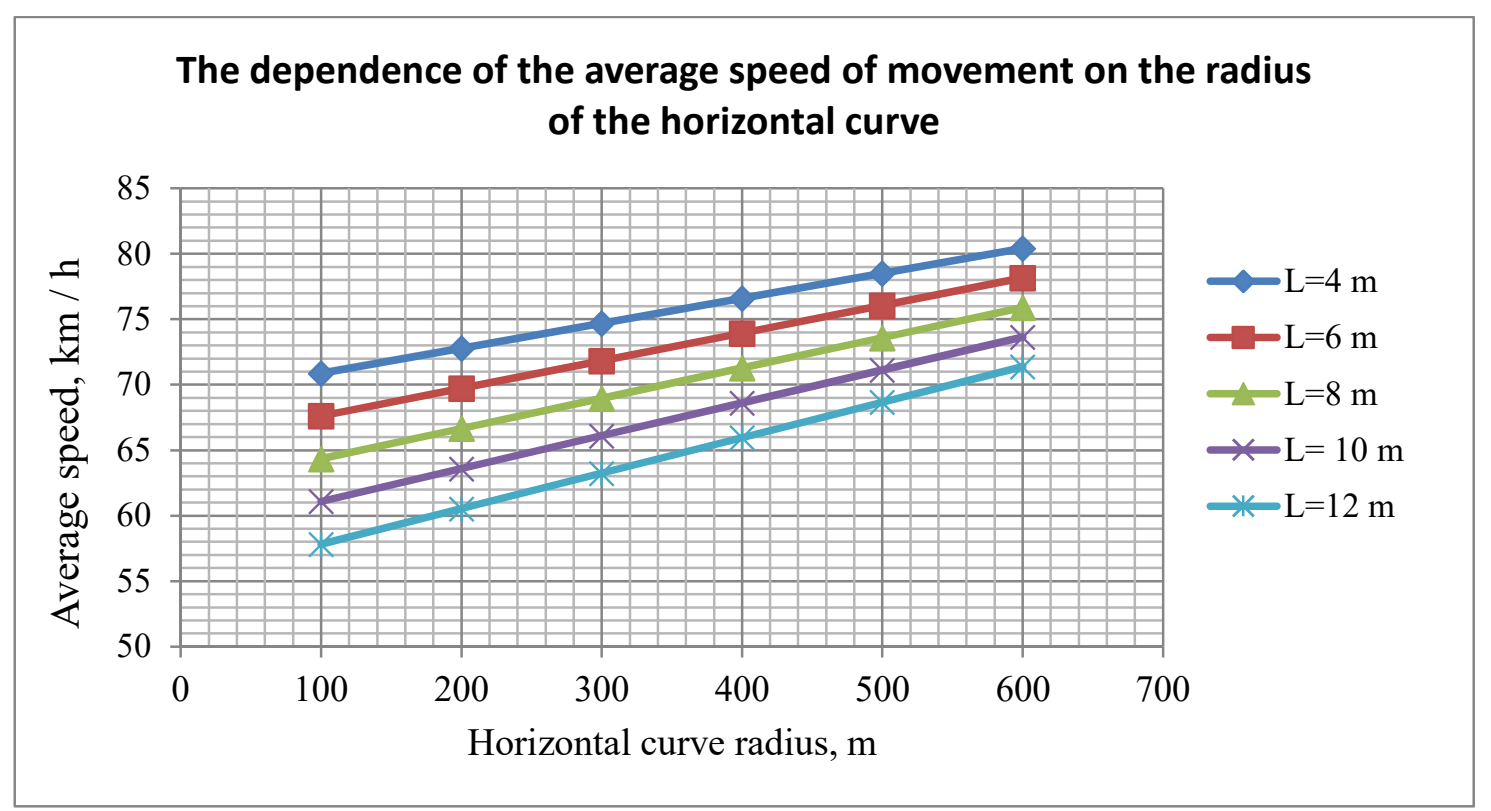

Figure 3 - Graph for determining the average speed of traffic flow depending on the radius of the horizontal curve from $100 \mathrm{~m}$ to $600 \mathrm{~m}$ and the average length of the car

Рисунок 3 - Графік по визначенню середньої швидкості руху транспортного потоку в залежності від радіуса горизонтальної кривої від 100 м до 600 м та середньої довжини автомобіля

The reduction of the average free-movement speed, depending on the longitudinal slope, is shown in Figure 4.

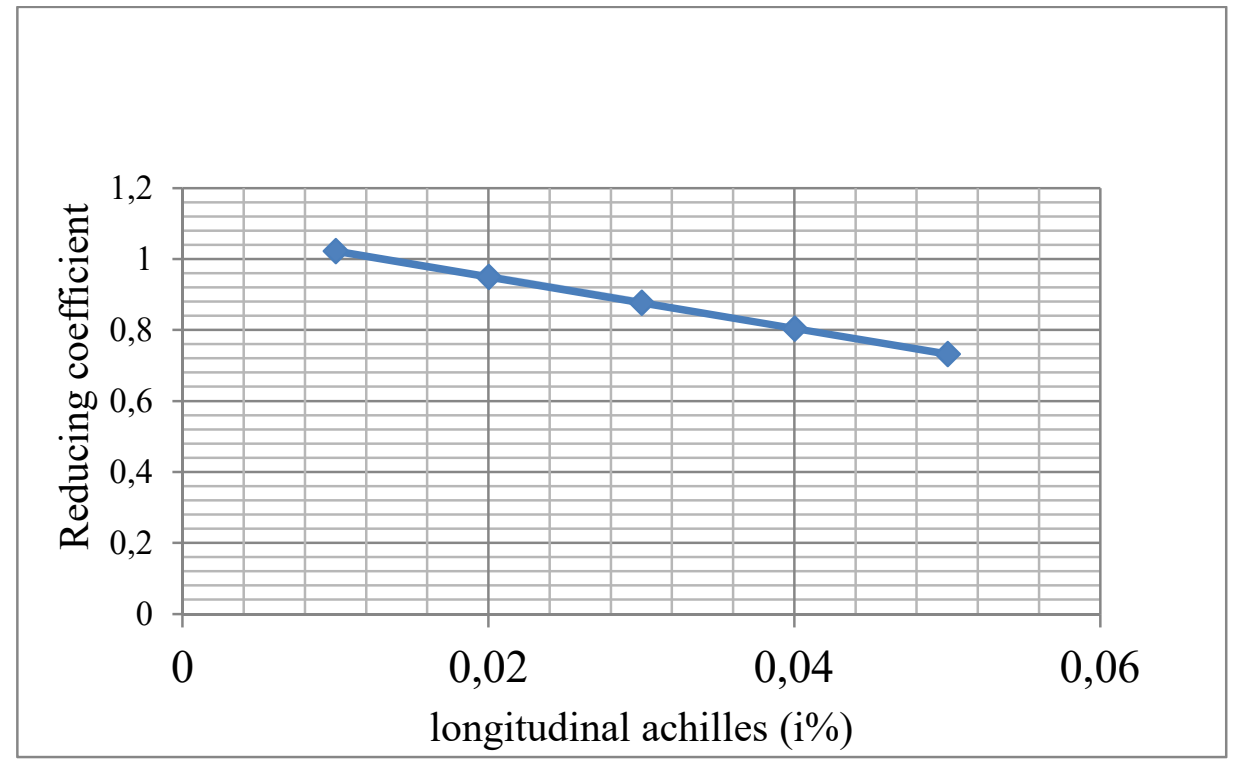

Figure 4 - Graph of the dependence of reducing coefficients on the longitudinal slope Рисунок 4 - Графік залежності знижуючих коефіцієнтів від поздовжнього похилу

The speed of the car is greatly influenced by the magnitude of the impact indicators, varying from 20 to $400 \mathrm{~cm} / \mathrm{km}$ :

$$
V=V_{B}-0,023 S,
$$

where $V_{B}$ - free-wheel speed, $\mathrm{km} /$ hour;

$\mathrm{S}$ - impulse indicator.

Науково-технічний збірник «АвТОмОБІљьн дОРОГи І дОРОжнє БУдІвницТвО» http://addb.ntu.edu.ua ISSN 0365-8171 (Print), ISSN 2707-4080 (Online), ISSN 2707-4099 (CD).

AUTOMOBILE ROADS AND ROAD CONSTRUCTION, 2021. Issue 109 
Based on the parameters of the highway and the presented dependencies, a graph of the speed of the motorway is formed, shown in Figure 5.

\begin{tabular}{|r|l|l|l|l|l|l|l|l|l|l|l|}
\hline & & & & & & & & & & \\
\hline \\
\hline
\end{tabular}

Figure 5 - Average speed graph

Рисунок 5 - Графік середньої швидкості руху

Direct and dashed lines show the direct and reverse motion of cars where:

$V_{p}$ - speed of movement depending on the equality of coverage;

$V_{n}$ - speed depending on the intensity of the movement;

$V_{i}$ - speed depending on the longitudinal slope;

$V_{r}$ - speed of movement depending on the radius of the horizontal curve;

$V_{b}$ - free movement speed;

$V_{o}$ - restriction of speed of traffic by means of traffic organization.

On the basis of the received graph, the time of the current route travel, as well as the fuel consumption, are determined. When calculating fuel consumption, it is necessary to take into account the elements of the road. When driving on the elevation, fuel consumption is increased by up to $20 \%$ according to the number of researchers. Increasing or decreasing the speed with respect to optimal speed increases fuel consumption up to $10 \%$ for every $10 \mathrm{~km} / \mathrm{h}$ of change in speed. $(1,2,3,4,9)$

Conclusion. During the determination of the cost and travel time on the road, in accordance with the task, the average speed of the vehicle is taken into account, including the parameters of the road and the condition of coverage. 


\section{References}

1. V.V.Fylypov, N.V. Smyrnova. Modelyrovanyetransportnыkhpotokovnadorohakh II-IV katehoryi. - M: KhNADU. - 2014 - 200s.

2. Bazovyenormyraskhodatoplyvadliaavtobusov y marshrutok. WWWnaviskanru.

3. Smyrnova N.V., Fylyppov V.P., Kyiashko D.M. Otsenkavlyianyianerovnosteidorozhnykhpokrytyinabezopasnostdorozhnohodvyzhenyia. Vestnyk KhADU-2009. - Release.47 - s. 63-45.

4. Smyrnova N.V. Osnovnыepolozhenyiaraschetazavysymostyraskhodatoplyvaotdorozhnykhuslovyi. Naukovyivisnykbudivnytstva - Kh. KhDTUBA, KhOTV ABU; 2014 - Vyp. 77- s.226-230.

5. Sylianov V.V. Sytnykov Yu. M. Raschetskorostydvyzhenyia pry proektyrovanyyavtomobylnыkhdoroh. TrudыMoskovskohoavtomobylno- dorozhnoho ynstytuta-1974-Vыp.72-s.47-66

6. Pal'chyk A.M. Transportnipotoky. K. NTU. 2010 -s. 171.

7. Metodykakompleksnoiotsinkybudivnytstva ta rekonstruktsiiavtomobilnykhdorih $\mathrm{z}$ urakhuvanniamsotsialno-ekonomichnoi ta ekolohichnoiefektyvnosti. M 218-02070915-630:2007-K.,2007. - 28s.

8. Dodukh K.M. Vyznachenniaserednoishvydkostivilnohorukhutransportnohopotoku. K: NTU, 2013, №69 s.188.

9. Krainyk L.V. Hrudel M.H. Dyferentsiiovanenormuvanniavytratpalyvavantazhnykhavtomobiliv ( VisnykDonetskohoinstytutuavtomobilnohotransportu №3 Donetsk, 2007 -s.19-20.

10. Dodukh K.M., Propusknazdatnistsmuhyrukhuavtomobilnoidorohy / A.M. Palchyk, K.M. Dodukh // Problemytransportu: zbirnyknaukovykhprats. - 2010. - Kyiv. - №7 - S. 94 - 100.

11. Dodukh K.M., Propusknazdatnistperekhreshchenavtomobilnykhdorih v odnomurivni / K.M. Dodukh // Problemytransportu: zbirnyknaukovykhprats. - 2010. - Kyiv. - №7 - S. $101-105$.

12. Dodukh K.M., Propusknazdatnistavtomobilnykhdorih / A.M. Palchyk, K.M. Dodukh, N.V. Neizvestna // Materialymizhnarodnoinaukovo-tekhnichnoikonferentsii «Proektuvannia, budivnytstvoiekspluatatsiianezhorstkykhdorozhnikhodiahiv»-Kharkiv: KhNADU, 2010. - S. 38 - 43.

13. Dodukh K.M., Propusknazdatnistsmuhyrukhuavtomobilnoidorohy / A.M. Palchyk, K.M. Dodukh // Materialymizhnarodnoinaukovo-praktychnoikonferentsii «Suchasnikompiuterno-innovatsiinitekhnolohiiproektuvannia, budivnytstva, ekspluatatsiiavtomobilnykhdorih ta aerodromiv» - Kharkiv: KhNADU, 2012. - S. $213-215$.

\section{ВПЛИВ ДОРОЖНІХ УМОВ НА ВИТРАТИ ПАЛИВА АВТОМОБІЛІВ}

Додух Катерина Михайлівна, к.т.н., доцент кафедри проектування доріг, геодезії та землеустрою, Національний транспортний університет.

https://orcid.org/0000-0003-2544-5359

Пальчик Антон Дмитрович, аспірант кафедри туризму, Національний транспортний університет. https://orcid.org/0000-0002-1467-3658

Анотація. В статті розглянуто питання впливу дорожніх умов на витрати палива автомобілями при перевезенні вантажів та пасажирів, які залежать від швидкості руху. Оптимальні витрати палива відповідають оптимальній швидкості руху, яка $є$ характеристикою для кожного типу автомобіля. Збільшення або зменшення швидкості руху від оптимальної приводять до збільшення витрат палива автомобілями. Наявність підйомів зменшує швидкість руху та збільшує витрати палива до 30\%. Дорожні умови (ширина проїзної частини, стан покриття, наявність горизонтальних кривих, поздовжніх похилів, пішохідних переходів, населених пунктів) викликає зміну швидкості руху та витрат паливо-мастильних матеріалів. Урахування дорожніх умов можливе через побудову графіка швидкості руху по маршруту, зміна швидкості руху виникає і на час проїзду та соціально-економічні показники проїзду маршруту.

Науково-технічний збірник «АвтОмОБльні дОРОГи І дОРОжнє БУдІвництво» http://addb.ntu.edu.ua ISSN 0365-8171 (Print), ISSN 2707-4080 (Online), ISSN 2707-4099 (CD). AUTOMOBILE ROADS AND ROAD CONSTRUCTION, 2021. Issue 109 
На основі цього графіка розраховуються витрати палива та час проїзду маршруту. Так як витрати палива складають 50-52\% вартості перевезень вантажів та пасажирів, то собівартість буде у 2 рази більша. Вартість перевезень вантажними автомобілями вантажів характеризується собівартістю перевезень, а перевезення пасажирів собівартістю та витратами часу пасажирів при проїзді маршруту.

Ключові слова: дорога, автомобіль, швидкість руху, витрати палива, час проїзду маршруту.

\section{Перелік посилань}

1. В.В.Филипов, Н.В. Смирнова.Моделирование транспортных потоков на дорогах II-IV категорий.- М: ХНАДУ. - 2014 -200с.

2. Базовые нормы расхода топлива для автобусов и маршруток.WWWnaviskanru.

3. Смирнова Н.В., Филиппов В.П., Кияшко Д.М. Оценка влияния неровностей дорожных покрытий на безопасность дорожного движения.Вестник ХАДУ-2009.-Вып.47 - с. 63-45.

4. Смирнова Н.В. Основные положения расчета зависимости расхода топлива от дорожных условий.Науковийвісникбудівництва - Х. ХДТУБА, ХОТВ АБУ; 2014 - Вип. 77- с.226-230

5. Сильянов В.В. Ситников Ю. М. Расчет скорости движения при проектировании автомобильных дорог. Труды Московського автомобильно- дорожного института-1974-Вып.72-с.47-66

6. Пальчик А.М. Транспортні потоки. К. НТУ. 2010 -с. 171.

7. Методика комплексної оцінки будівництва та реконструкції автомобільних доріг з урахуванням соціально-економічної та екологічної ефективності. М 218-02070915-630:2007-К.,2007. - 28с.

8. Додух К.М. Визначення середньої швидкості вільного руху транспортного потоку. К: НТУ, 2013, №69 c.188.

9. Крайник Л.В. Грудель М.Г. Диференційоване нормування витрат палива вантажних автомобілів ( Вісник Донецького інституту автомобільного транспорту №3 Донецьк, 2007 -c.19-20

10. 2. Додух К.М., Пропускна здатність смуги руху автомобільної дороги / А.М. Пальчик, К.М. Додух // Проблеми транспорту: збірник наукових праць. - 2010. - Київ. - №7 - С. 94 - 100.

11. Додух К.М., Пропускна здатність перехрещень автомобільних доріг в одному рівні / К.М. Додух // Проблеми транспорту: збірник наукових праць. - 2010. - Київ. - №7 - С. 101 - 105.

12. Додух К.М., Пропускна здатність автомобільних доріг / А.М. Пальчик, К.М. Додух, Н.В. Неізвестна // Матеріали міжнародної науково-технічної конференції «Проектування, будівництво і експлуатація нежорстких дорожніх одягів» - Харків: ХНАДУ, 2010. - С. 38 - 43.

13. Додух К.М., Пропускна здатність смуги руху автомобільної дороги / А.М. Пальчик, К.М. Додух // Матеріали міжнародної науково-практичної конференції «Сучасні комп'ютерно-інноваційні технології проектування, будівництва, експлуатації автомобільних доріг та аеродромів» - Харків: ХНАДУ, 2012. - С. $213-215$.

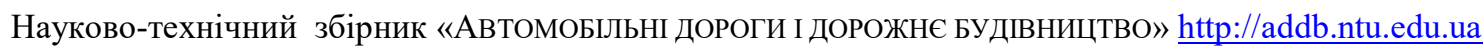
ISSN 0365-8171 (Print), ISSN 2707-4080 (Online), ISSN 2707-4099 (CD).

AUTOMOBILE ROADS AND ROAD CONSTRUCTION, 2021. Issue 109 